\title{
Re G (Children)
}

Court of Appeal: Maurice Kay and Munby LJJ and Sir Stephen Sedley, 4 October 2012 [2012] EWCA Civ 1233 Divorce - Orthodox Jews - upbringing of children

The children's divorced parents were Orthodox Jews. The father, an ultra-Orthodox Chareidi, wanted them to attend single-sex Chareidi schools, while the mother, no longer a member of the Chareidi community, wanted to send them to 'modern orthodox' coeducational schools where boys and girls participated equally in most activities. She brought proceedings under Part II of the Children Act 1989 and HHJ Copley ordered that, with effect from September 2012, they should attend the schools proposed by the mother. The court dismissed the father's appeal and, in doing so, stressed that it was not the court's business to examine the religious beliefs of the parties. Munby LJ stated that:

[t]he starting point of the common law is ... respect for an individual's religious principles, coupled with an essentially neutral view of religious beliefs and a benevolent tolerance of cultural and religious diversity. It is not for a judge to weigh one religion against another. The court recognises no religious distinctions and generally speaking passes no judgment on religious beliefs or on the tenets, doctrines or rules of any particular section of society. All are entitled to equal respect, so long as they are 'legally and socially acceptable' and not 'immoral or socially obnoxious' or 'pernicious'.

He added that this position was commensurate with the Strasbourg jurisprudence under which a state could not determine the validity of religious beliefs but was under a duty of what the Strasbourg court has called neutrality and impartiality. [Frank Cranmer].

doi:10.1017/So956618X13000069

\section{Re St Paul, Woldingham (No 2)}

Southwark Consistory Court: Petchey Ch, 29 October 2012 Telecommunications installation - licence fees

The chancellor had adjourned the determination of this petition for the installation of telecommunications equipment in a church and for the team vicar and parochial church council to enter into a licence agreement with New Edge 
Telecommunications (Net) Limited (NET) to maintain, operate and use the equipment (reported at (2013) 15 Ecc LJ 119) in order to receive answers to a number of concerns he had identified in relation to the terms of the licence agreement. The chancellor's concerns centred around the fact that NET was essentially a monopoly purchaser of the right to put telecommunications equipment in churches, such that it was not possible to assess the value of that right in relation to a particular church.

The chancellor received further evidence from the petitioners, including material of particular commercial sensitivity, which sensitivity he was asked to respect in his judgment and allow NET to comment on a draft judgment. The chancellor chose not to view such material, on the basis that his judgment and the reasons for it should be transparent. In granting the faculty sought with minor amendments to the terms of the licence, the chancellor expressed concerns about the basis upon which the size of the licence fee was reached. The licence fee was a fixed standard fee dependent upon the size of the conurbation within which the church was located, with no scope for adjustment to take account of the value of a particular site. Nevertheless, the fact that there were five-yearly upward-only licence fee reviews incorporated in the terms of the licence, which might themselves be used to re-negotiate the licence fee to reflect the value of a particular site, meant that what was proposed was not unreasonable. [RA]

doi:10.1017/So956618X13000070

\section{KS v TS}

Dunfermline Sheriff Court: Sheriff Ian D Dunbar, 1 November 2012 Divorce - Muslim/Christian couple - children's religious upbringing

The parents, a woman from a Brethren family who had ceased to practise when she turned eighteen and an Egyptian Muslim man, had married in 2001. They had twin boys (circumcised with the mother's written consent) and a girl. After the marriage breakdown in 2010 the mother started attending her parish church and from the beginning of 2012 took the children to church when they were staying with her, though she only gave them food that was halal. Equally, the father had become a more observant Muslim and had started taking the children with him to the mosque. The father regarded raising his children as Muslims as a religious obligation and, as part of the proceedings, sought an order to that effect, believing that attending the parish church as well as the mosque would merely confuse them. The mother believed that the children should be brought up to understand both 